\title{
愛媛県における地すべり地域の地表勾配
}

\section{Gradient of Ground Surface of Landslide Area in Ehime Prefecture}

\author{
高 木 方 隆* 中 村忠 春** 宮 内 定 基** \\ Masataka TAKAgI Tadaharu NAKAMURA Sadaki MIYAUCHI
}

\begin{abstract}
Landslide phenomena are caused by many factors such as of the land, geological features, properties of soil, water balance and others.

We collected many data over more than 20 years, in order to analyzed on mechanism of the landslides called HASAITAI JISUBERI occurred in SHIKOKU ISLAND.

In this paper, we studied statistically on the distribution of gradient of ground surface between the normal area and the landsliding area, and the following conclusions were obtained.

1. Both distribution of gradient of ground surface are different in half of cases, and be same in rate of tenth.

2. Slopes having landsliding are grouped into 4 types, and each type is appeared with defined protortion.

3. Landslides occur in all lay of the land.

4. Landslides area makes good use for farmland.
\end{abstract}

\section{1. はじめに}

四国の地すべりは, 高知県の長者・怒田, 徳島県の山 域, 愛媛県の沃渡などを除くと規模が小さく, 多発崩壊 型あるいは連発崩壊型のものが多く, 渡の言らいわゆる 青年型・壮年型の地すべりである ${ }^{2)}$ 。現に動いている筒 所は案外局限されており, 愛媛県での農地地すべり防止 区域内では $3 \%$ 程度の面積に過ぎなかった。例えば1200 $\mathrm{mm}$ におよぶ連続集中豪雨のあった昭和51年10月災害の 際でも, 地すべり地域の被害は他地域に比べむしら少な かった。しかし初めて動いた国領川左岸の渡瀬地すべり などは広範囲な動さがみられたが，もちろん対処工の効 果もあるが，54年度苂害には山腹中斜面がやや動いた程 度に過ぎなかった4)。すなわち四国の地すべりは大規模 な現状変更や集中豪雨が引金となる初発型の動きの際は 広範囲大規模に動くが，その後の動きは案外穏やかであ る。前述の長者・怒田・山城・沢渡などの大規沢地すべ り地も, 動きについて許容度のある水田をはじめとする 農地や林地としてほぼ全面的に利用されているほどであ る。

したがって地すべり防止区域内に散在している小規模 な地すべり简所と，すべっていない部分との地表勾配は 如何なる関係にあるものかを考察し, 四国の地すべり地

* 受媛大学大学院

** 愛媛大学農学部
域における地表勾配の実態を考察しょうとするものであ る。それには現地を調査確認し，しかも一貫して 2 千分 の 1 地形図が整備され, 統計的考察を耐え得る愛媛県の 構造改善指定87地区と，それに含まれる460の地すべり 発生箇所とを考察の対象とした。

\section{2. $20 \mathrm{~m}$ 勾配からの考察}

2 万分の 1 地形図（等高線間隔 $2 \mathrm{~m}$ ) 上で可能な限り ミクロな地表勾配を求めた。具体的には図上に直径 1 $\mathrm{cm}$ の円を描き，この円内の等高線数を円中心における 勾配と見なした。したがって最もミクロな地表勾配とい っても, 実際には $20 \mathrm{~m}$ 径円内の平均地表勾配ということ になる。地表勾配 $i$ は円内の等高線数を $n$ とすると次式 で表され，勾配は等高線数 $n$ で代表できることになる。

$$
i=\tan ^{-1}(2 n / 20)
$$

\section{2-1 縦断方向における地表勾配の起伏}

地表はどの様に起伏しているかを考察してみよう。そ れには 2 万分のの 1 地形図上で，斜面の繸断線上に連続 する直径 $1 \mathrm{~cm}$ 円内の等高線数, つまり $20 \mathrm{~m}$ 勾配を(1) 式を用いて求めてみた。

まず地すべり防止地域ごとに，（図-1）に例示するA 測線のように，地すべりが発生していない任意の一般斜 面の縦断線上に拈いて，屋根から谷まで，20m勾配が増 加傾向から減少傾向, 減少傾向から増加傾向に移行する 点【勾配変化点と仮称 (図 -2 参照)】間の水平距離 $l$ を 


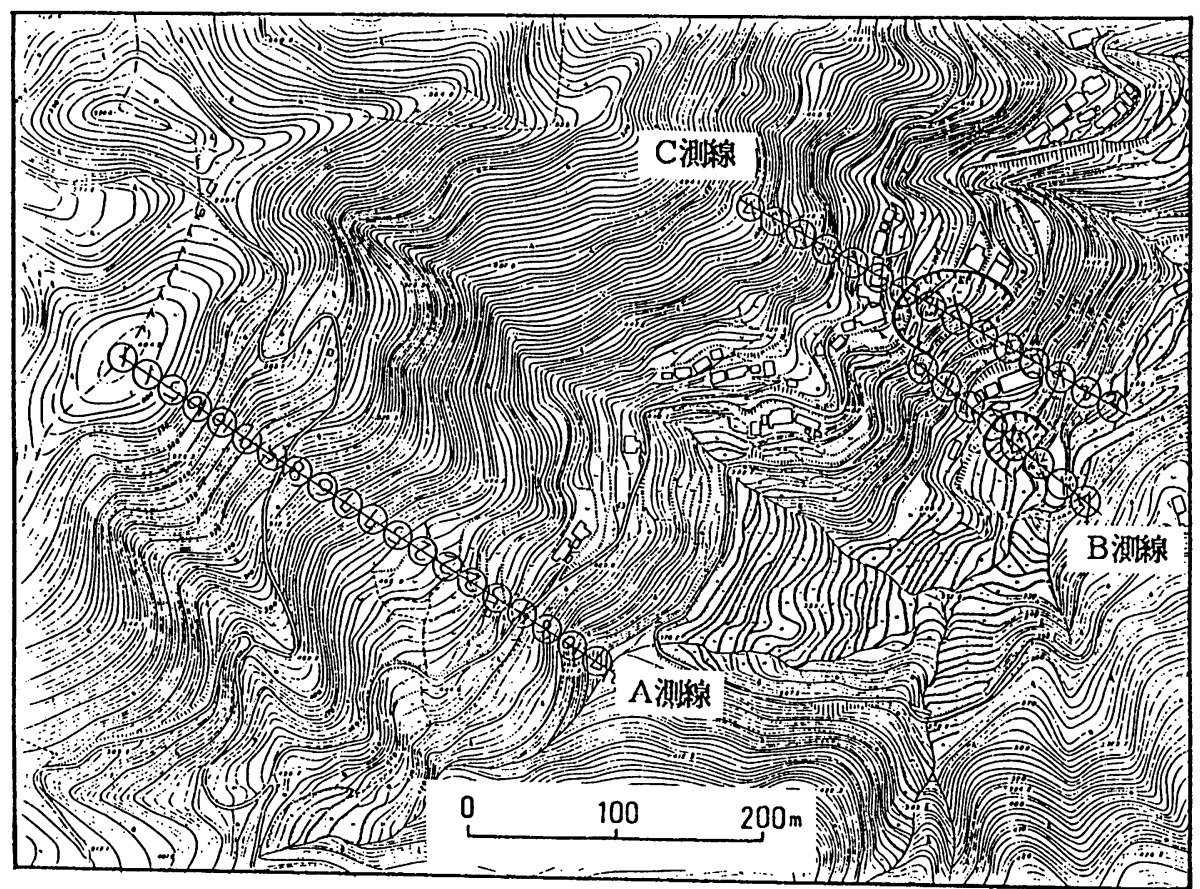

O内の数字は等高線数

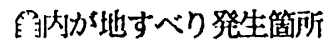

图-1 $20 \mathrm{~m}$ 縦断勾配の测定例（福住地区）

求めてみた。約 $45 \%$ の防止区域が $20 \mathrm{~m} て ゙$ 勾配傾向が変っ ており $100 \mathrm{mを}$ 越えて変わるものは $5 \%$ に過ぎなかった

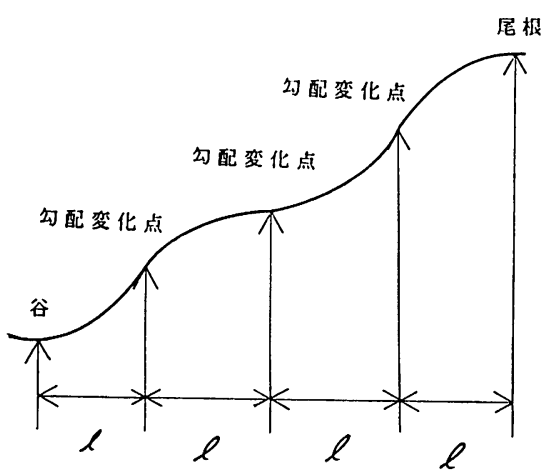

图-2 勾配変化点の概念図

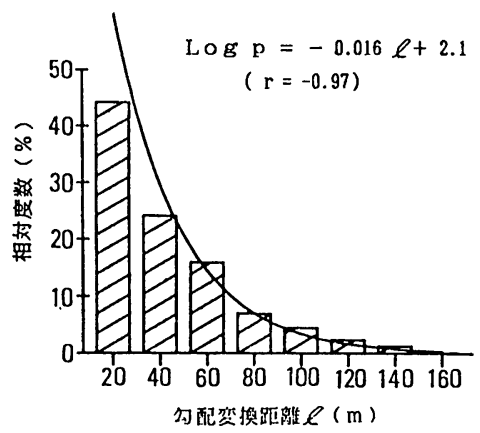

图-3 周辺斜面におけ万勾配変化点間の距離 1 の出現頻度
(図-3)。

ついで同じ防止区域内で（図-1）飞例示する B・C 測線上の図示範囲内のように，地すべり発生簓所での縦 断線上に拈ける勾配変化点間距離 $l$ を求めてみると, 全 体の64\%がやはり 20m で傾向が変わって拈り，100mを越 えて変わるものは僅か $1 \%$ 過ぎなかった（図-4）。 勾配変化点間距離 $l$ とその出現割合 $p$ との関係は, 一 般斜面・地すべり箅所ともに非い相関があり次のようだ った。

一般斜面：相関係数 $r=-0.97$

$\log p=-0.016 l+2.1$

地すべり籄所：相関係数 $r=-0.99$

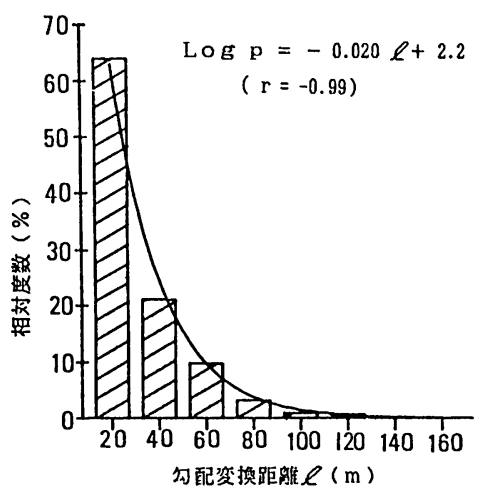

図-4 地すべり発生筒所におけろ勾配変化点間距離 $l$ の 現頻度 
$\log p=-0.020 l+2.2$

すなわち地すへり地域の地表勾配は, 勾配変化距離の 短いものの割合が多い。つまり地形は小刻みに起伏して いるが，地すべり発生简所ではこの傾向がより強い。

\section{2-2 地表勾配の出現頻度}

対象地域全域に打ける地表勾配の実状を考察してみよ う。それには地すべり防止区域の 2 千分の 1 地当図上に 東西・南北方向を座標とした $1 \mathrm{~cm}$ 方眼をかけ, その方 眼交点を中心とする直径 $1 \mathrm{~cm}$ の円を描き, 防止区域ご とに全域全ての $20 \mathrm{~m}$ 勾配と地すべり発生筒所全ての $20 \mathrm{~m}$ 勾配とを求めた。

\section{2-2-1 地すべり発生筒所における代現頻度}

各地すべり防止区域内全域での $20 \mathrm{~m}$ 勾配は，87地区中 83地区 (95.4\%) が $\chi^{2}$ 検定により危険率 $5 \%$ で正規分 布していた。正規分布していない 4 地区は, 平坦地や棚 田が極端に卓越し勾配分布に偏りがあるためなので, 考 察から除外した。

正規分布している83地区に拈ける20m勾配の平均值を みると（図- 5 ), $2 \leqq n<8\left(11.3^{\circ} \sim 38.7^{\circ}\right)$ と広範囲に あるが，約 8 割の64地区は特に $4 \leqq n<6\left(21.8^{\circ} \sim 31.0^{\circ}\right)$ に集中して持り，防止区域は急傾斜地であるといえよ 万。

さらに，各防止区域における $20 \mathrm{~m}$ 勾配の平均值と変動 係数との関係を見ると（図-6），相関係数一 0.73 をっ て平均值が大きい地区ほど変動係数は小さくなり，乙か も変動係数の分布幅もそれに連れて狭くなっている。

すなわち防止区域はほとんど急傾斜地にあるといえる が，勾配平均の急な地区ほど，勾配のばらつきが少なく 単調な地形であり, 平均值が同じ地区同士のばらつき程 度もその程度が少なくなることが解った。

2-2-2 地すべり発生筒所に括ける出現頻度

各防止区域内に括ける地すべり発生笝所全てでの $20 \mathrm{~m}$ 勾配は，83地区中58地区（69.9\%）だけが $\chi^{2}$ 検定によ り危険率 $5 \%$ で正規分布していた。なお正規分布してい ない25地区を見ると，ピークが 2 つ有ったり，急あるい は緩勾配が多かったり，ある特定勾配に集中したりして 偏っていた。

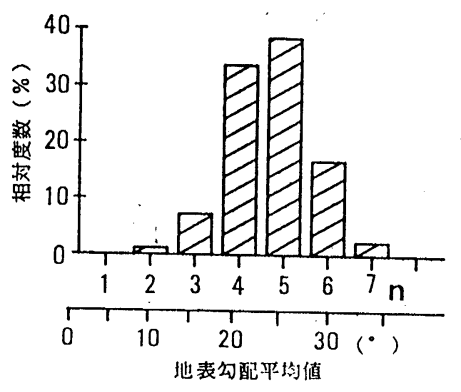

图-5 各地すべり防止区域における地表公配平均傎の 出現頻度
正規分布している58地区に拈ける地すべり発生筒所で の，20m勾配の各地区ごとの平均值をみると（図-7）， $2 \leqq n<8\left(11.3^{\circ} \sim 38.7^{\circ}\right)$ と防止区域全域での分布範囲と 同じである。しかし約 8 割の45地区は $3 \leqq n<6(16.7 \%$ ～ $31.0^{\circ}$ )、に集中し，集中範囲は防止区域全域の場合より も緩勾配にまで及んでいる。

さらに, 各防止地区域での発生箇所の $20 \mathrm{~m}$ 勾配平均值 と変動係数との関係を見てみよう（図-8）。地すべり防

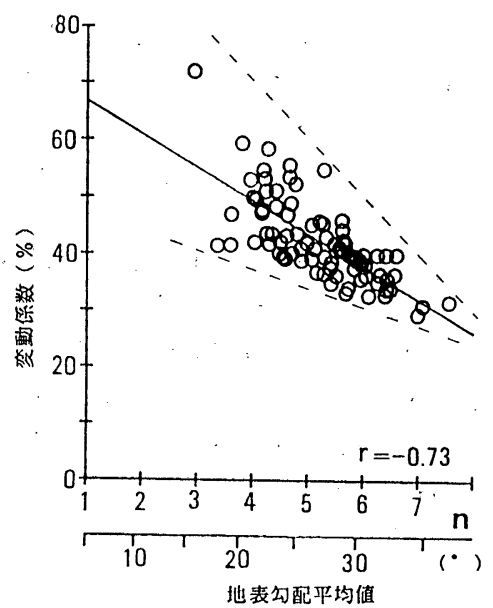

図-6 各地すべり防止区域における地表勾配平均值と変動係 数之の関係

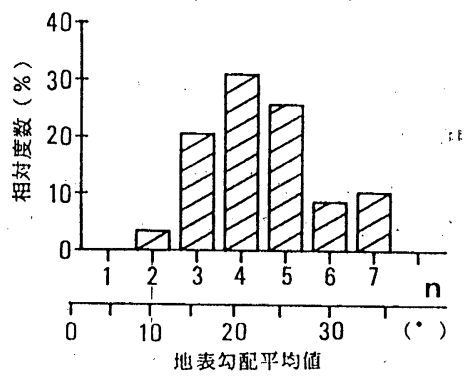

図-7 各地すべり防止区域での地すべり発生筒所における地 表勾配平均値の出現頻㾗

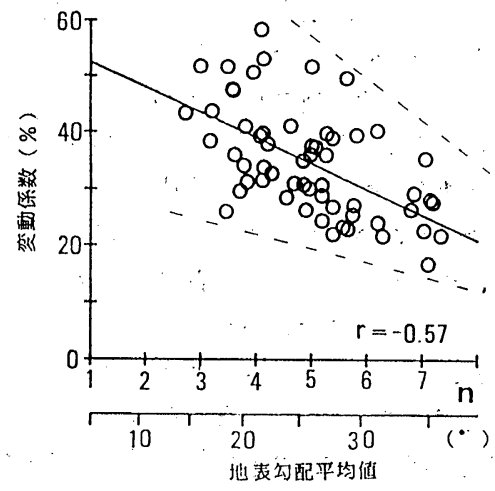

図-8 各地すべり防止区域での地すべり発生筒所における地 表勾配平均值と変動係数との関係 
止区域での傾向と同様に，平均值が大きい地区ほど変動 係数は小さくなっている。しかし相関係数はー0.57 と低 く, 何れの平均值での変動係数の值自体は常に小さく, 変動係数の分布幅は常にほぼ同程度でしかも広い。

すなわち発生筫所での地表勾配は, 防止区域全域に比 ベやや平均勾配が緩やかあり，勾配のばらつきは，やは り平均值が急なほどばらつきが少なくて単調な地形であ る。しかしばらつきの程度自体はより少なく, 平均值が 同じ地区同士でのばらつき程度もその程度がより大きい つまり地すべりの発生は, 平均勾配をやや和らげ勾配変 化を単調にするが 地区によってそのばらつき程度に差 があることが解った。

2-2-3 地すべり防止区域と発生䉪所との地表勾配の 差異

地すべり発生简所とそれの属する防止区域と両者の地 表勾配は, 同じ母集団に属するか否か, 各防止区域ごと に平均值と分散とについて危際率 $5 \%$ で $\mathrm{F}$ 分布検定を行 った。な統計処理は正規分布しているものにしか行え ないことから，防止区域・発生简所ともに正規分布して いる約 7 割の58地区を対象とした。その結果は,

(1) 勾配の平均值, 分散ともに適合していない地区 27 地区 $(47 \%)$

(2) 勾配の平均值に関してのみ適合している地区13地 区 $(22 \%)$

(3) 勾配の分散に関してのみ適合している地区12地区 (21\%)

(4) 勾配の平均值, 分散ともに適合している地区 6 地 区 $(10 \%)$

つまり，それぞれが正規分布している防止地域と地す ベり発生簡所との地表勾配をみると, 全く異なる地区が ほほ半分で，全く同じ地区は約 1 割であった。また平均 勾配なり、ばらつき程度なり，どちらかが同じである場 合が残り半分ずつ，つまり約 2 割ずつだった。

すなわち，地すべりの発生によって地表勾配は当然変 化するが，地すべり防止区域の地表勾配出現頻度を統計 的に考察してみると，地すべり発生箇所の地表勾配は約 3 割が特定勾配に偏って扣り正規分布していなかった。 正規分布している約 7 割のらち半ばは全く別集団と見な されたから，約6.5割つまり約 $2 / 3$ の地区は確かに地す ベりにより地表勾配の出現頻度が異なっている。しかし 正規分布するもののうち, 他の半ば約 3.5 割つまり残り 約 $1 / 3$ の地すべり地区では, 地表勾配が全く別集団とは 言いきれなかった。すなわちその約 $1 / 5$ は全く同集団 と見なされ，その $2 / 5$ ずつは平均值なりばらつきなり が母集団と同じであった。つまり四国の地すべり地域に

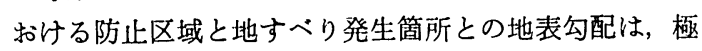
端な变化の違いは案外ない上うにみられる。

\section{3. 区間勾配からの考察}

地すべりの発生斜面ごとに，地すべり䉪所区間とそれ に続く上・下段両間との勾配関係はいかなるものか, 各 区間の平均勾配によってややマクロに考察してみたい。

\section{3-1 各区間勾配}

地すべり箇所ではその全水平距離 $L$ 間の平均勾配をそ の区間勾配としたが，それに続く上・下段斜面では縦断 勾配が急変する尾根, 谷, 海岸までの間の平均勾配を区 間勾配とした。しかしそれらに至る距離が長くなる場合

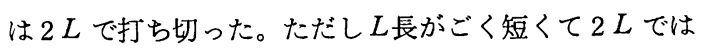
十分に勾配を代表し得ないと判断された場合には, より 長くなっても妥当とみられる距離で平均した。

まず地すべり箇所とそれに続く上・下段との各区間勾 配の出現頻度（因一9)を求めてみた。な拈各区間勾配の 平均は，地すべり简所で $25.4 \pm 9.4^{\circ}$, 上段で $24.8 \pm 8.6^{\circ}$ 下段で24. $7 \pm 10.7^{\circ}$, 全区間で $25.0 \pm 9.6^{\circ}$ とほぼ同じだ った。

また区間勾配全部（母集団）と各区間勾配（標本集 団）とのマハラノビス距離を求めてみた。つまり母集団 を $N\left(\mu, \sigma^{2}\right)$ とし, 比べる標本集団の平均值を $(\bar{X})$ と すれば,

マハラノビスの距離 $=(X-\mu) / \operatorname{SQRT}\left(\sigma^{2} / n\right)$

母集団がT分布に従うとすれば, この場合, 距離の絶 対值が1.98以下ならばそれぞれ同集団とみなすことがで きる。マハラノビス距離は上段区間とはー0.29, 地すべ り简所とは 0.52 , 下段とはー0.35でいずれも同集団とみ られ，その出現箇所（図-9）も怙互いに良く似ている。

すなわち地すべり䉪所区間とそれに続く上・下段両区 間の勾配を，各区間ごとの平均勾配でマクロに見てみる と、いずれの区間勾配も統計的には同じものであった。

\section{3-2 斜面タイプ}

3-2-1 区間勾配変化と斜面タイプ

地すべり筒所の区間勾配が，それに続く上・下段各区 間勾配よりも急か緩かによって, 次の 5 つの斜面タイプ

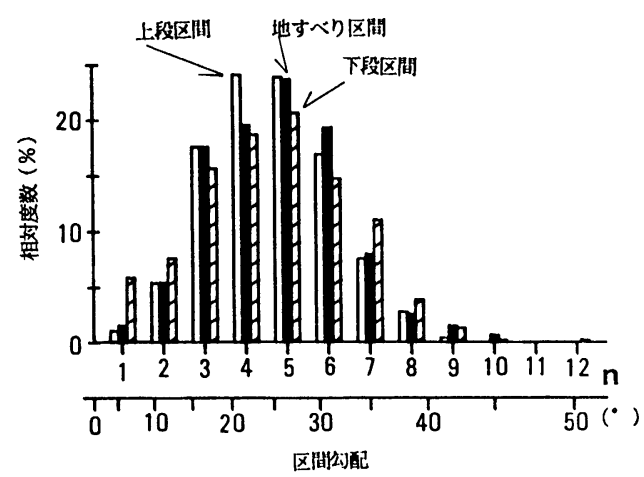

図-9 地すべり区間とそれに続く上・下段区間における 各区間勾配の出現頻度 

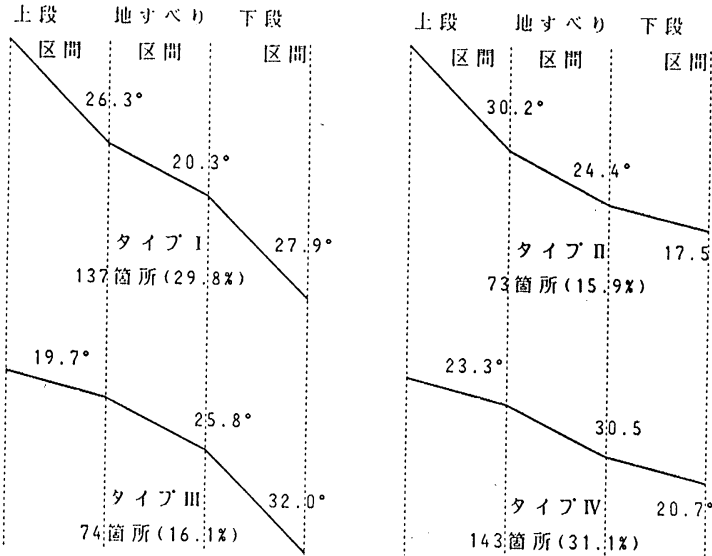

図-10 地すべり斜面における各タイプの概念図

に分類できる（図-10）。なお各タイプごとに上段 $\rightarrow$ 地す べり箇所 $\rightarrow$ 下段の順に各区間勾配の平均值を示す。

斜面タイプ I ：上・下段より緩なもの。

$\left(26.3 \rightarrow 20.3 \rightarrow 27.9^{\circ}\right)$ の137简所 $(29.8 \%)$

斜面タイプ II：上段よりは緩かで下段よりも急なもの。

$\left(30.2 \rightarrow 24.4 \rightarrow 17.5^{\circ}\right)$ の73籄所 $(15.9 \%)$

斜面タイプIII：上段よりは急で下段よりは緩なもの。

$\left(19.7 \rightarrow 25.8 \rightarrow 32.0^{\circ}\right)$ の74筫所 $(16.1 \%)$

斜面タイプIV：上・下段よりも急なもの。

$\left(23.3 \rightarrow 30.5 \rightarrow 20.7^{\circ}\right)$ の143箇所 $(31.1 \%)$

斜面タイプ V : 上段或は下段と同じもの。

$\left(23.7 \rightarrow 24.2 \rightarrow 25.6^{\circ}\right)$ の33简所 $(7.1 \%)$

なおタイプVは，I〜IV各タイプの特殊例と見なされ 出現率も少ないので，考察より除外した。な拈このタイ プVの地すべり㯺所は水平距離 $L$ が $20 \mathrm{~m}$ 円にして 2 個以 下と小さいものが汪とんどであった。

次に上段・地すべり䉪所・下段を通じての各区間勾配 の変化といら面から考光てみよう。タイプ II は上段から 下段にかけて区間勾配が次第に緩になり，全体的に凹形 の単調な斜面勾配を示している。逆にタイプIIIは区間勾 配が次第に急になって, 全体的に凸形の単調な斜面勾配 を示している。いっぽらタイプ I とタイプIVは急な区間 勾配 ( $25^{\circ}$ 程度以上) と緩な区間勾配 ( $25^{\circ}$ 程度以下) とが交互に現われるもので，地すべり籄所の区間勾配が， タイプIでは緩くタイプIVでは急なだけの違いである。

表-1 全斜面タイプにおける各区間での区間勾配（母集団） と，各斜面における各区間での区間勾配（標本集四） とのマハラノビス距離

\begin{tabular}{|c|c|c|c|c|}
\hline 区䦨面多件 & タイブI & タイブII & タイブIII & タイプIV \\
\hline 全区間 & -0.13 & -0.95 & 1.28 & -0.06 \\
\hline 上段区間 & 2.25 & 9.43 & -9.20 & -2.38 \\
\hline $\begin{array}{l}\text { 地すべク区間 } \\
\text { 下段区間 }\end{array}$ & $\begin{array}{r}-8.01 \\
4.70\end{array}$ & $\begin{array}{r}-1.55 \\
-10.61\end{array}$ & $\begin{array}{r}0.65 \\
10.11\end{array}$ & $\begin{array}{r}7.67 \\
-4.84\end{array}$ \\
\hline
\end{tabular}

3-2-2 斜面タイプと区間勾配

まず全斜面タイプの 全区間つまり全ての区間勾配 （母集団）と各斜面 タイプごとの全区間の 区間勾配 （標本集団）とのマハラノビス 距離（表-1）を求め てみた。やはり絶対值1.98以下で同集団と見なし得る が，緩急交互する斜面タイプ I ・ IVは 0.1 前後で非常 に近く, 単調斜面タイプ II ・ III 1.0 前後で非常に近 いとは言えないが，いずれにしろ同集団と見なし得る。 次いで全斜面タイプの 各区間での区間勾配（母集 団）と，各斜面タイプごとの同じ区間での区間勾配 （標本集団）とのマハラノビ ス 距離を求めてみたが （表-1），やはり絶対值が1.98以下の場合に同集団と 見なし得る。地すべり简所の区間勾配については，単 調な斜面勾配タイプ II ・IIIは絶対值0.6 1.5 程度で母 集団と同じとみられるが，緩急交互斜面タイプI・IVは 絶対值 8 前後で別集団とみられた。上・下段の両区間勾 配については，いずれのタイプも絶対值が1.98以上で別 集団とみられた。なお緩知交互斜面夕首プ I ・IVは上段 で絶刘值2.3程度，下段で絶対值4.8前後とやや母集団に 近く離れているが，単調斜面タイプ II ・ II 值9.3程度，下段で絶対值10.4前後と大きく離れている。

すなわち，地すべり筒所区間とそれに続く上・下各区 間とを全てひっくるめて区間勾配を見ると，いずれの斜 面タイプも同集団に属し，あえて各タイプを区別するほ ぞではなかった。しかし地すべり箇所区間とそれに続く 上・下段各区間とは別々に分けて各区間勾配を見ると， 地すべり箇所では単調斜面タイプだけが同集団と見なさ れ，交互斜面は別集団であった。上・下段各区間では全 て別集団であったが，交互斜面タイプが単調斜面タイプ よりも母集団に近かった。つまり，斜面全区間に着目す るといずれの斜面タイプる同集団と見なされたが，地す ベりの简所区間だけに着目すると笚調斜面タイプが，発 生していない上・下段区間だけに着目するとどちらかと いえば単調斜面タイプよりも交互斜面タイプの方が地す ベり斜面の性格を代表しているといえよう。地すべりは 地形を単調にしようとしているのかも知れない。

な叔各区間受に各タイプの区間勾配出現パターン(罒一 11〜13）を示すが，区間勾配全ての 出現パターン（図9）と比較すると, 各区間別の区間勾配出現パターンは 斜面タイプによって差があることがよく解る。

\section{3-2-3 斜面タイプの出現割合}

斜面タイプの出現割合について考光てみよう。ただし タイプVは, 各タイプの特殊例と見なされ出現割合も少 ないので除外すると, タイプ I は137简所(32.1\%), タイ プIは143箇所（33.5\%)でそれぞれ約 1/3，タイプIIは

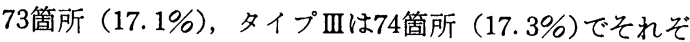
れ約 1 / 6 出現している。

上段の区間勾配が，地すべり箶所のそれより急な（タ 
イプI・II）綏な（タイプIII・IV）と，あるいは下段の 区間公配が，地すべり簡所のそれより急な（タイプI・ III）緩な（タイプII・IV）とに分けると，いずれもほぼ

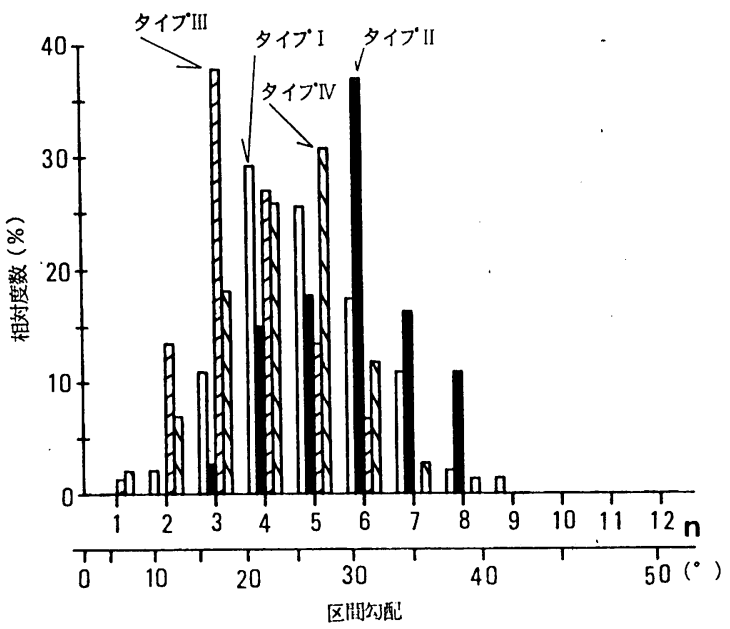

図-11上段区間勾配の各斜面タイプ別出現頻度

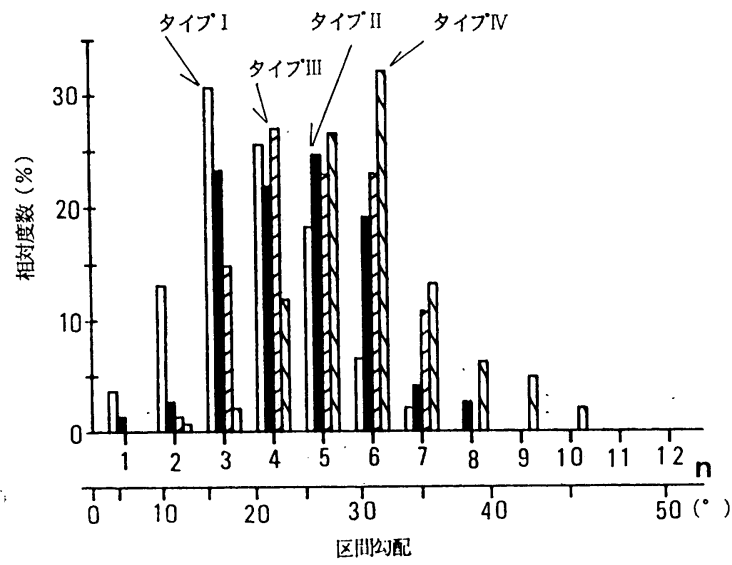

图-12 地すべり区間の各斜面タイプ別出現頻度

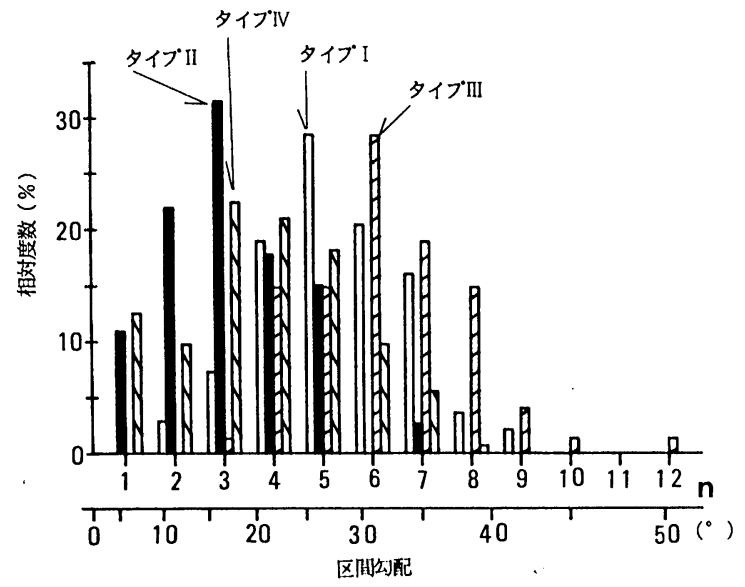

图-13 下段区間勾配の各斜面タイプ別出現頻度
1/2ずつを占めることになる。つまり地すべり簡所と上 段あるいは下段の各区間とを比軦した場合，急な場命と 緩な場合はほぼ同率に出現していることになる。

また，緩急両勾配が交互する（タイプI・IV）は全 体の $2 / 3$ を占めるが，上下段に比べ地すべり簡所が 緩勾配の（タイプI）と愛勾配の（タイプIV）とでは それぞれ同率で1/3ずつを占めている。公配が単調 な（タイプ II・II）は全体の $1 / 3$ を占めるが 凹形 斜面の（タイプII）と凸形斜面の（タイプIII）とはそ れぞれ同率なので1/6ずつを占めている。さらに地 すべり箇所が緩勾配部分に相当する（タイプI・II） と，急勾配部分に相当する（タイプ III IV）とは，そ れぞれ同率 1 / 2 ずつを占めている。

なお，斜面はいずれ緩急両勾配が交互するものだと いら立場にたつと，緩急両勾配が交互する(タイプI・ IV) と勾配が単調な（タイプII・III）との迹いは単に 勾配変化の波長の違いにすぎない。つまり(タイプ II ・ III）は単調凹型斜面のタイプ II と単調凸型斜面のタイ プが連続して初めて交互することになる。すなわ ち単調な（タイプII・III）は，交互する（タイプI・ IV）に比べはるかに長波長だが，緩急交互するといら 立場からは半分の役割しか果していない。したがって 単調な（タイプII ・III）があわせて $1 / 3$, 交互する

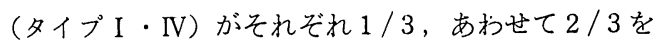
占めることになるのであろう。

さらに地すべり発生は水系と密接な関係にあるの で1) 水系流域別に各斜面タイプの出現頻度を調べてみ た（表-2）。発生筫所が約30箇所を越える流域になる と,タイプI・II ・III IV が 1/3:1/6:1/6: $1 / 3$ に近い出現割合を示しだす。つまり斜面は緩急 両勾配が交互しているものだといら立場にたつと，如 何なる斜面タイプも同様な比率で出現しているらしい ことが，同条件の地すべり箅所を30䉪所以上も大量観 察をしてみると推定できよう。

すなわち，大量観察して得た各斜面タイプの出現割 合を種々な勾配パターンに組み合わせて考察してみる と，斜面は緩急両勾配が交互しているものだといら立 場に立つと常に同率平等な発生割合になっている。つ まり地すべりは，いかなる斜面タイプを生ずるにしろ， 全ての斜面で同率平等に発生しているらしい。

\section{4. すべり箇所の利用状況}

地すべり発生箇所全面積について，その利用状況を （表-3）飞示す。林地が最も多く34.1\%を占め，次い で樹園地 $26.8 \%$, 水田 $22.6 \%$, 畑地 $14.5 \%$, 荒れ地 1 $\%$ ，宅地 $1 \%$ の順である。地すべり箅所と言えども荒 れ地として放棄したり，危険なのに宅地として利用し ているのはごく少なく，非常に有効に利用されている 
表-2 水系別にみた地すべり斜面タイプの出現頻度

(単位 : 簡所)

\begin{tabular}{|c|c|c|c|c|c|c|}
\hline 水系名 & 河川名 & $\begin{array}{l}\text { 斜面 } \\
\text { タイプ I } \\
\end{array}$ & $\begin{array}{l}\text { 斜面 } \\
\text { タイブII }\end{array}$ & $\begin{array}{l}\text { 斜面 } \\
\text { タイプIII }\end{array}$ & $\begin{array}{l}\text { 斜面 } \\
\text { タイプ }\end{array}$ & 合計 \\
\hline 胧川 & $\begin{array}{l}\text { 胠川 } \\
\text { 小田川 } \\
\text { 河辺川 } \\
\text { 田渡川 } \\
\text { 中山川 } \\
\text { 麓川 }\end{array}$ & $\begin{aligned} & 10(25.0 \%) \\
& 32(37.2 \%) \\
& 3(50.0 \%) \\
& 5(20.8 \%) \\
& 15(34.1 \%) \\
& 3(15.8 \%) \\
&\end{aligned}$ & $\begin{array}{rr}5 & (12.5 \%) \\
17 & (19.8 \%) \\
1 & (16.7 \%) \\
6 & (25.0 \%) \\
4 & (6.8 \%) \\
2 & (10.5 \%)\end{array}$ & $\begin{array}{rr}8 & (20.0 \%) \\
16 & (18.6 \%) \\
1 & (16.7 \%) \\
3 & (12.5 \%) \\
4 & (9.1 \%) \\
6 & (31.3 \%) \\
\end{array}$ & $\begin{aligned} & 12(30.0 \%) \\
& 19(22.1 \%) \\
& 1(16.7 \%) \\
& 5(20.8 \%) \\
& 15(34.1 \%) \\
& 6(31.3 \%) \\
&\end{aligned}$ & $\begin{array}{l}44 \\
19\end{array}$ \\
\hline 仁淀川 & \begin{tabular}{|l} 
面河川 \\
黒川 \\
久万川 \\
直瀬川 \\
\end{tabular} & $\begin{aligned} & 9(21.4 \%) \\
& 3(20.0 \%) \\
& 10(30.3 \%) \\
& 10(47.6 \%) \\
&\end{aligned}$ & $\begin{array}{l}4(9.5 \%) \\
0(0 \%) \\
7(21.2 \%) \\
2(9.5 \%)\end{array}$ & $\begin{array}{l}9(21.4 \%) \\
4(26.7 \%) \\
5(15.2 \%) \\
2(9.5 \%)\end{array}$ & \begin{tabular}{rr|}
15 & $(35.7 \%)$ \\
8 & $(53.3 \%)$ \\
11 & $(33.3 \%)$ \\
4 & $(19.0 \%)$ \\
\end{tabular} & $\begin{array}{l}42 \\
15 \\
33 \\
21\end{array}$ \\
\hline 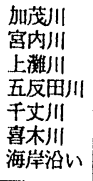 & & $\begin{aligned} 1 & (12.5 \%) \\
2 & (22.2 \%) \\
5 & (35.7 \%) \\
7 & (53.8 \%) \\
1 & (16.7 \%) \\
4 & (30.8 \%) \\
13 & (23.6 \%)\end{aligned}$ & $\begin{array}{rr}2 & (25.0 \%) \\
2 & (22.2 \%) \\
2 & (14.3 \%) \\
1 & (7.7 \%) \\
3 & (50.0 \%) \\
5 & (38.5 \%) \\
11 & (20.0 \%)\end{array}$ & $\begin{array}{ll}0 & \left(\begin{array}{ll}0 & \%\end{array}\right) \\
1 & (11.1 \%) \\
6 & (42.9 \%) \\
1 & (7.7 \%) \\
1 & (16.7 \%) \\
2 & (15.4 \%) \\
5 & (9.1 \%)\end{array}$ & $\begin{array}{rr}5 & (62.5 \%) \\
4 & (44.4 \%) \\
1 & (7.1 \%) \\
4 & (30.8 \%) \\
1 & (16.7 \%) \\
2 & (15.4 \%) \\
23 & (41.8 \%)\end{array}$ & $\begin{array}{r}14 \\
13 \\
6 \\
13 \\
55\end{array}$ \\
\hline
\end{tabular}

表-3 地すべり篰所の利用状沅別地表勾配出現頻度

\begin{tabular}{|c|c|c|c|}
\hline 利用状況 地表勾配 & 平均值n (伤度) & 標淮编差 & 袈動俰数 \\
\hline 森林 $: 87.36$ ha $(34.1 \%)$ & $5.94 \quad\left(31^{*}\right)$ & 2.20 & 37.0 \\
\hline 果樹園 : 68.56 ha (26.8\%) & $4.70 \quad\left(25^{\circ}\right)$ & 1.37 & 41.9 \\
\hline 水田 : 57.92 ha (22.6\%) & $4.04 \quad\left(22^{\prime}\right)$ & 1.90 & 47.0 \\
\hline 烟地 : 37.16 ha $(14.5 \%)$ & $4.91 \quad\left(26^{\circ}\right)$ & 1.85 & 37.7 \\
\hline 旒れ地： 5.04 ha $(1.0 \%)$ & $4.94 \quad\left(26^{\prime}\right)$ & 1.96 & 39.7 \\
\hline 宅地： 5.88 ha ( $1.0 \%)$ & $3.22\left(18^{\circ}\right)$ & 1.52 & 47.2 \\
\hline
\end{tabular}

といえよう。

これら地すべり発生䈯所における土地利用地目別に地 表勾配出現頻度を求めてみると， $\chi^{2}$ 検定により危険率 $5 \%$ ずずて正規分布していた。したがって各地目別に 勾配平均值と変動係数を求めた（表-3）。すなわち, 勾配 平均值は林地が $3.1^{\circ}$ と最も急で, 果樹園・畑地は, $2.5^{\circ}$ 〜 26ํやや緩勾配, 水田は農地で最も緩勾配の $22^{\circ}$ であ った。一方変動係数は, 宅地・水田が最も大きく $47 \%$, ついで果樹園が $42 \%$ と大きく，これらは石垣積み・棚田 ・段畑であることが大きく反映されている。なお地形を そのまま利用する畑や林地は37〜38\%に過ぎない。

地すべり発生简所の地表勾配は，今まで述べてきたよ うに統計的にみれば周辺部分との差は案外少なく，やや 勾配も緩く利用し易い。また水系近傍に発生する1)こと から水が豊富で, 地すべり現象によって土層も梁いため, 農林地として積極的に利用されている。実際, 地すべり 災害として大きく取り沙汰され始めたのは戦後のことで, 大型機械の導入にともない, 大規模な農地造成，交通路 整備が可能になり，地すべり地域は地盤の動きに対する 許容量が大幅に狭いので災害として浮き彫りにされ始め たと考えられる。

\section{5. まとめ}

四国の地すべりは，小規模なものが散在多発し，地 すべりそのものの面積は防止区域の一部を占めるに過 ぎない1)。

まず，この散在している局部的な地すべりの発生部 分と発生していない一般的な周辺部分とでは地表勾配 がぞの様に違らか，2千分の 1 地形図上で最もミク口 な $20 \mathrm{~m}$ 勾配を（1）式で求め統計的に考察してみた。

(1) 地すべり地域の地表勾配は, 勾配変化距離の短 いものの割合が多い。つまり地形は小刻みに起伏して いるが，地すべり発生箅所ではこの傾向がより強い。

(2)防止区域はほとんど急傾斜地にあるといえるが， 勾配平均の急な地区ほど，勾配のばらつきが少なく単 調な地形であり，平均值が同じ地区同士のばらつき程 度もその程度が少なくなる。

(3) 発生箅所での地表勾配は, 防止区域全域に比べや や平均勾配が緩であり, 勾配のばらつきは, やはり平均 值が急なほどばらつきが少なくて単調な地形である。し かしばらつきの程度自体はより少なく, 平均值が同じ地 区同士でのばらつき程度もとの程度がより大きい。つま り地すべりの発生は, 平均勾配をやや和らげ勾配変化を 単調にするが, 地区によってそのばらつき程度に差があ る。

(4)地すべりの発生によって地表勾配は当然変化する が，地すべり発生箅所の地表勾配は約 3 割が特定勾配に 偏っており正規分布していなかった。正規分布している 約 7 割のらち半ばは全く別集団と見なされたから, 計 6.5割つまり約 $2 / 3$ の地区は確かに地すべりにより地表 勾配の出現頻度が異なっている。残り約 $1 / 3$ の地すべ り地区では，地表勾配が全く別集団とは言いきれなかっ た。すなわちその約 $1 / 5$ は全く同集団と見なされそのの $2 / 5$ ずつは平均值なりばらつきなりが母集団と同じで あった。つまり四国の地すべり地域に括ける防止区域と 地すべり発生箅所との地表勾配は, 極端な変化の違いは 案外ないよらにみられる。

次いで，地すべり筫所区間とそれに続く上・下段の各 区間とでは，斜面勾配がどのように関連しているか，や やマクロな各区間の平均勾配をもって統計的に考察して みた。

(1) いずれの区間勾配も統計的には同じものであった。

(2) 地すべり箅所区間の平均勾配が上・下段のそれよ りも急か緩かによって 4つの斜面タイプに分類した（図 -10)。すなわち念緩急（タイプI），緩急緩（タイプIV） である緩急交互タイプと，次第に緩で凹型（タイプII）, 次第に急で凸型（タイプ而）を示す単調斜面タイプとで ある。

(3) 斜面全区間に着目するといずれの斜面タイプも同 
集団と見なされたが，地すべりの简所区間だけに着目す ると単調斜面タイプが，発生していない上・下段区間だ けに着目するとどちらかといえば単調斜面タイプよりも 交互斜面タイプの方が地すべり斜面の性格を代表してい るといえよう。地すべりは地形を単調にしょうとしてい るのかも知れない。

(4)さらに地すべり発生筒所といえども，農林地とし て積極的に土地利用されている。

したがって起伏している急傾斜地域に発生し，やや偏 りはあるが勾配を和らげる方向に生じているといえよう。 しかしそれに続く一般斜面と一貫した斜面としてマク口 にみると，地すべり部分もとれに続く上・下段部分も平 均斜面両勾配としてすべてが同質であり，地すべりはい かなる斜面タイプであるにしろ同率平等に発生している ことになる。

地すべりは, 地形, 地質, 土質, 水文など各面から様 々な要素が複雑に絡み合っていて, 研究面からみると学 際的な存在である。さきに四国の地すべり分布を取り上 げ，四国の地すべりは地形的に新しい侵食圈内に生じ， 水系と密接に関連しながら小規模なものが多発・連発し ているもので, 現在の地形形成の問題でもあるらしいと 述べた ${ }^{11}$ 。今回の地表勾配の考察からも地すべりは確か に現地形を崩してはいるが，やや巨視的にみると現地形 の形成について平等に責任負担しているらしいといえよ う。

なお農地地すべり地区のデータを用いたので土地利用 が農林地に偏っているともみられるが，四国の地すべり
防止区域は山間部に位置し各機関指定のものが混在して いるので, 林野庁指定地域はもちろん, 建設省指定地域 も農林地の比率こそ少ないが，危険な地すべり简所を宅 地にしたりはせず，また放棄もせず生活の糧としてほと んど亚林地に利用していることを付記したい。

最後になったが，この研究を進める上で地形図など提 県, 高知県の農林水産部, 関係市町村には, この場をか りて厚く批礼申し上げる次第である。

\section{参考文献}

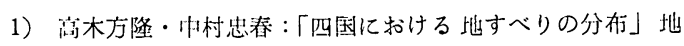
すべり

2）渡正 亮:「地すべりの型と対策」地すべり8(1), 1971

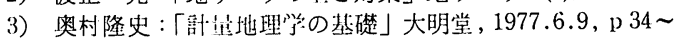
105

4）今西欽哉・広自孝也・原田敏雄：「中央構造線と地すべり」 地すべり学会関西支部現地討論会, $1984.11, \mathrm{p} 1 \sim 12$

5）理論計量地理学研究会, 日本システム開発研究所：「影地

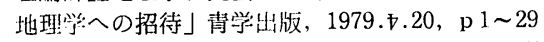

6） A.E.シャイデッガー, 奥时筃夫訳 :「理論地理学」古今皆 院, 1980.8.4, p 263 299

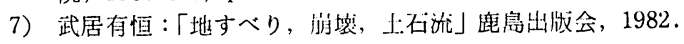
$4.20, \mathrm{p} 206 \sim 210$

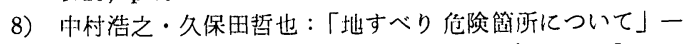
公配と地質からみた危䧍度一地すべりVol.123， No.4， $1987, \mathrm{p} 6 \sim 12$

9）永井浩三：「爱媛の地形」受媛地学会, $\mathrm{p} 21 \sim 47,1987.12$. 20

10）舆谷川修一・大野裕紀・永峰良則「四国地域の 2 少 5 線分 の 1 斜的崩壊地形分類図の作成について」土啠工学会四国 支部, 地すべり学会関西支部, 斜面崩壤及び地すべりの予 知と対策仪関するシンポジウム, $1988.10, \mathrm{p} 103$ 1 10

(原稿受理日平成元年 7 曷31日)

\section{地学雑誌特別号「粉・粒体と地学」}

（社）東京地学協会は, 下鶴大輔東大名誉教授を特別号 委員長として, 標記の地学雑誌特別号を, 第89巻第 6 号 1989年として, 平成元年12月に発刊したが, 同誌の通号 900 の記念号である。その英文タイトルは, Particulate and Granular Materials and Earth Sciences である。

この特別号は, 1. 細粒物質の成因, 2. 細粒物質の堆積 状態と環境, 3. 細粒物質の堆積・運動のメカニズム, 4. 細粒物質の運動力学, 5. 生活に関係する実例という, 全 地球的及び国際的な背景を踏まえて論文を構成している。

この構成は, 最近高まりつつある地球環境の問題及び ICSU (国際学術連合)によって提唱された IGBP（国際 地圈・生物圈プログラム）と深い関係にあることを考兄 ると, この特別号の発刊の意義は深い。

論文は, 岩石の破壊による粒子のサイズ分布(水谷仁), テフラとマグマの発泡・破砕・流動 (寅丸敦志), 諸環 境に括ける堆積物 の粒度測定法 (遠藤邦彦), 花崗岩山 地を供給源とする堆積物の異なる環境に拈ける粒度組成
(森山昭雄), 堆積物の粒度組成の分析々侵食環境の堆定 (柏谷健二), 粒状体としてのしらすの諸特性 (山内豊聡). 軟弱地盤・液状化現象 (陶野郁雄), 砂粒の移動機構(河 野恵昭), 粉粒液相としての堆積物重力流の運搬機構(徐 垣・平朝彦), 高速煙り型雪崩 (前野純一), ダイレイタ ンシー (大中康誉), 液体中の微粒子の挙動 (奥山喜久 夫), 成層圈に注入される火山夾 (下鶴大輔), エアゾル 々地球環境 (河村公隆), 粒状体の力学 (佐竹正雄), 粒 状体の運動一数值シミュレーション (伯野元彦), 粉㘍 爆発（榎本兵治）, 粉粒体輸送 (山崎量工・吉田邦夫) か ら成っている。

1 部の定価は送料込み 1,100 円で，下記に申し込めば 送付される。

下102 東京都千代田区二番町12-2 東京地学協会, 振替口座 東京 $0-66278$

(山内壹聡) 